\title{
Development of safe optimized welding procedures for high strength Q\&T steel welded with austenitic consumables
}

\author{
(Desenvolvimento de procedimentos de soldagem seguros e otimizados para aços temperados e revenido de alta \\ resistência com consumíveis austeníticos)
}

\author{
Lenka Kuzmikova, Huijun Li, John Norrish, Zengxi Pan and Nathan Larkin \\ University of Wollongong, NSW, Australia
}

\begin{abstract}
High strength quenched and tempered (Q\&T) steels offer obvious economic benefits originating from their advantageous strength to price and weight ratios. These steels are usually welded using ferritic consumables and for this combination the risk of hydrogen assisted cold cracking (HACC) is high. The use of austenitic stainless steel (ASS) consumables has great potential to significantly improve this issue. Yet, there are no guidelines for determination of safe level of preheat for welding ferritic steels with ASS consumables. For this reason manufacturers adopt this parameter from procedures developed for conventional ferritic consumables thus significantly limiting the benefits ASS consumables are capable to deliver. Productivity could be further enhanced by identifying the upper interpass temperature threshold, thus reducing the stand-off times. Aim of this work is to develop safe highly optimised procedures for welding of high strength Q\&T steel with ASS consumable.
\end{abstract}

\section{Resumo}

Aços temperados e revenidos de alta resistência (Q\&T) oferecem vantagens econômicas óbvias originadas de sua benéfica razão resistência e custo ou peso. Estes aços são normalmente soldados com consumíveis ferríticos e, por esta causa, apresentam alto risco de trinca de hidrogênio. O uso de consumíveis de aços inoxidáveis austeníticos representa um grande potencial para melhorar este aspecto. Entretanto, não há recomendações técnicas para determinar um nível seguro de temperatura de pré-aquecimento para soldagens de aços ferríticos com consumíveis austeníticos. Por isto, fabricantes adotam para este parâmetro os tirados de procedimentos desenvolvidos para consumíveis ferríticos convencionais, consequentemente reduzindo os benefícios que os consumíveis austeníticos poderiam fornecer. Produtividade poderia ser intensificada pela identificação da temperatura de interpasse, reduzindo os tempos mortos. O objetivo do presente trabalho foi o de desenvolver procedimentos seguros e altamente otimizados para soldagens dos aços temperados e revenidos de alta resistência com consumíveis de aços inoxidáveis austeníticos.

\section{Introduction}

In fabrication of steel structures productivity and costeffectiveness of the welding process significantly affect the price of the final product. Therefore, ways of improving these factors are constantly being reviewed and advanced solutions are being implemented.

The main concern when welding Q\&T steels is the risk HACC. Common practice to avoid this defect from occurring is to employ sufficient pre or post heating of the weldment. However, both these treatments represent an additional step in the welding process, significantly reduce productivity and increase fabrication costs. Further, post weld heat treatment is not recommended for Q\&T steels due to stress relief cracking [1].

Industry partner initially welded high strength Q\&T steel in high hardness condition with ferritic consumables and preheating

Recebido em 18/02/2013. Texto final em 25/02/2013. was necessary even for thin sections to reduce the cooling rate and allow additional time for hydrogen to diffuse out of the joint. Despite this measure the risk of HACC was still very high as it was difficult to ensure that these restricted procedures were narrowly followed in every day manufacturing practice. The use of flux-cored ASS consumable offered optimum solution to this problem as it has got much higher solubility and considerably lower diffusivity of hydrogen compared to ferritic fillers. However the level of preheat remained unchanged due to the lack of guidance on welding ferritic steel with ASS consumable provided by welding standards.

Various methods of determination of minimum level of preheat ensuring freedom from HACC are summarised in ISO/ TR 17844 [2]. For a given chemistry and heat treatment history this standard advises to use so called CET method. Following this method the minimum preheat temperature was calculated to be $78^{\circ} \mathrm{C}$. This value is in good agreement with the preheat temperature range used in the industry practice $\left(80-120^{\circ} \mathrm{C}\right)$ originally developed for ferritic filler. This document further states that preheat can be reduced when ASS consumable is used as a result of better strain condition and hydrogen distribution 
across the weldment. Lower levels of preheat are also permissible for multi-pass welding if adequately high inter-pass temperature is maintained in between the deposition of the single passes assisting the diffusion of hydrogen out of the areas of previous passes. However, no indication of the lower safe threshold for welding ferritic steels with austenitic stainless steel consumable is provided.

Further to reduce the risk of HACC adequate inter-pass temperature in between deposition of the single passes has to be maintained. Inter-pass temperature range is typically identical with preheat. High strength Q\&T steels are not only prone to HACC but also to excessive softening of heat-affected zone (HAZ) and over-tempered region that can compromise the properties of the welded structure. From productivity view point it is beneficial to employ highest inter-pass temperature that does not produce extensively wide areas with high degree of softening. However when designing welding procedures the selection of inter-pass temperature ensures only freedom from HACC and the upper threshold is not usually explored. This is not necessary for conventional manual and semi-automatic welding. The customers demand to increase the production outputs indicated necessity to explore fully automatic processes utilising welding robots that can achieve very high welding speeds, thus information about the higher inter-pass temperature thresholds became desirable.

Productivity could be further improved by employing metalcored wire instead of currently used flux-cored. Flux-cored wire produces slag deposit on the surface of the weld. In case of multipass welding, the slag needs to be removed before deposition of the subsequent pass. This introduces additional difficulty for automation and is disadvantageous in terms of both productivity and cost. Additionally, the flux also has the potential to pick-up hydrogen from the surrounding atmosphere if the consumable is stored inappropriately or over a long period of time. This hydrogen can be absorbed by the weld pool, increasing the risk of HACC. Other advantages of the metal-cored wire include higher duty cycles, faster travel speeds, low fume formation and very good cost effectiveness. This makes this wire ideal candidate for automated processes.

The objective of this work was to develop safe highly optimised procedures for fully automated welding of high strength Q\&T steel with metal-cored ASS consumable by identifying the lower preheat and upper inter-pass temperature threshold.

\section{Materials}

The chemical composition of the investigated high strength
Q\&T steel is listed in Table 1. The microstructure of the plate in Q\&T condition consists of tempered martensite with an average hardness of $519 \mathrm{HV}$ and is shown in Figure 1.

The alloy design of this steel utilises the novel low manganese approach in order to reduce centreline segregation of $\mathrm{MnS}$ inclusions and thus improve mechanical properties and weldability. The steel is microalloyed with $\mathrm{Nb}, \mathrm{Ti}, \mathrm{V}$, and $\mathrm{B}$ in order to increase hardenability and enhance the HAZ properties.

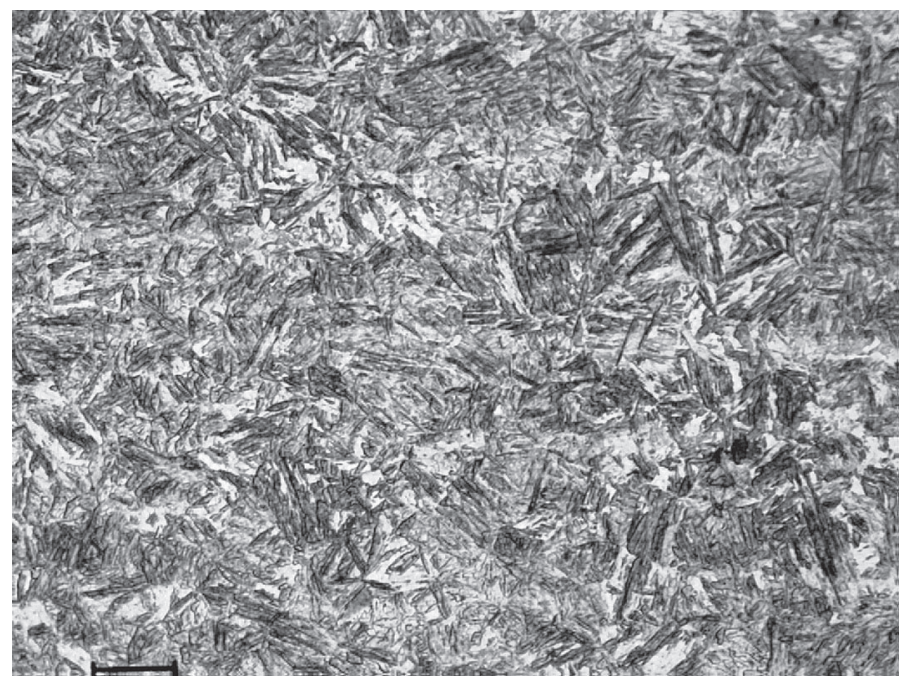

Figure 1 Representative microstructure of investigated steel in Q\&T condition. Note the micron bar represents $20 \mu \mathrm{m}$.

Metal-cored consumable AWS A5.9 EC308Mo type is ideal candidate for fully automated welding and was selected for this investigation. It is a versatile gas shielded, seamless wire capable of out of position welding and exhibits enhanced productivity and wetting action when compared to equivalent solid wire.

\section{Experimental procedure}

\subsection{Welding set-up}

To determine the lower preheat temperature threshold, single pass fillet weld configuration was selected and is shown in Figure 2 - a. This arrangement is the most susceptible to HACC as the HAZ is not tempered by the subsequent passes. Samples were welded with following levels of preheat $5^{\circ} \mathrm{C}$ (simulating ambient temperature during winter periods), $20^{\circ} \mathrm{C}$ and $80^{\circ} \mathrm{C}$ (current industry practice).

Table 1 Chemical composition of $8.5 \mathrm{~mm}$ HHA steel in wt \% max.

\begin{tabular}{|l|l|l|l|l|l|l|l|l|}
\hline Element & $\mathbf{C}$ & $\mathbf{M n}$ & $\mathbf{S i}$ & $\mathbf{N i}$ & $\mathbf{C r}$ & Mo & S & $\mathbf{P}$ \\
\hline $\mathrm{Wt} \% \max$ & 0.32 & 0.4 & 0.35 & 0.35 & 1.15 & 0.3 & 0.005 & 0.02 \\
\hline
\end{tabular}

\begin{tabular}{|c|c|c|c|c|c|c|c|c|}
\hline Element & $\mathbf{C u}$ & $\mathbf{A l}$ & $\mathbf{N b}$ & $\mathbf{T i}$ & $\mathbf{V}$ & $\mathbf{B}$ & $\mathbf{C E}_{\text {IIw }}$ & $\mathbf{P}_{\mathbf{c m}}$ \\
\hline $\mathrm{Wt} \% \max$ & 0.2 & 0.06 & 0.005 & 0.03 & 0.05 & 0.002 & 0.72 & 0.46 \\
\hline
\end{tabular}



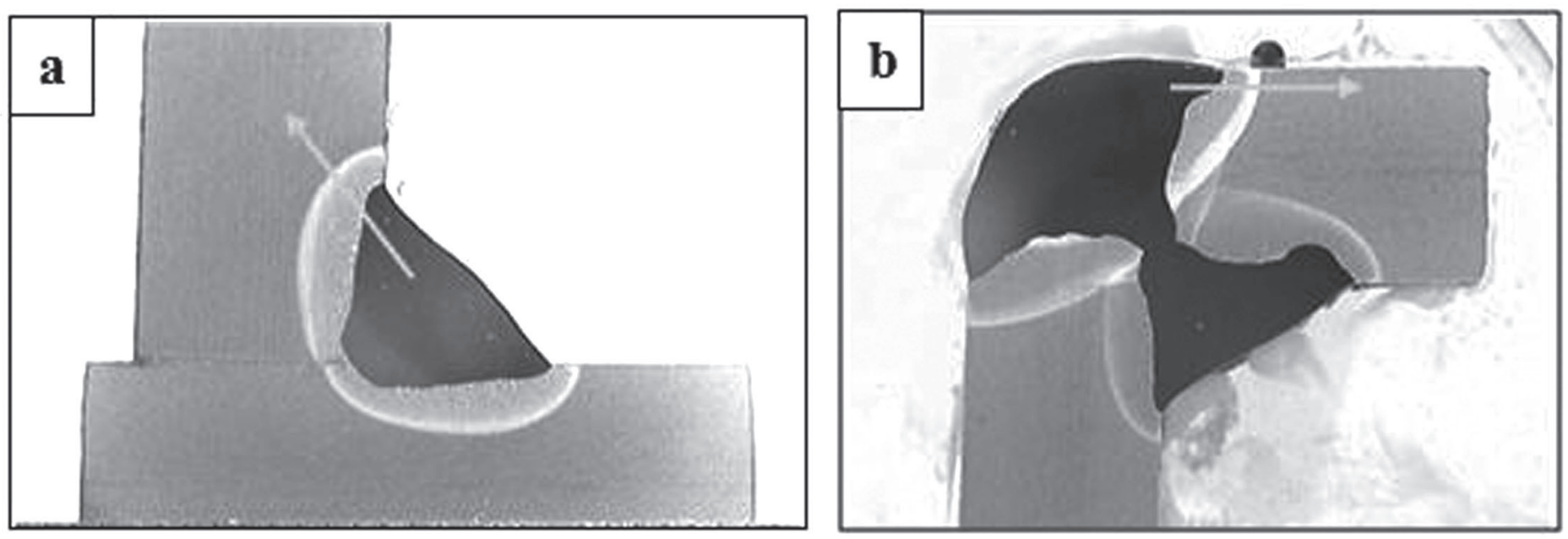

Figure 2 Macrophotograph showing the weld geometry and orientation of hardness traverses for: $a-$ single and b - multi-pass weldments.

The deposition of multiple passes can result in formation of extensively wide softened zones especially when high heat inputs or inadequately high inter-pass temperatures are employed. Therefore to optimise the inter-pass temperature multi-pass corner joint configuration shown in Figure $2-b$ was used for this investigation. Inter-pass temperatures of $120^{\circ} \mathrm{C}$ (current industry practice), $200^{\circ} \mathrm{C}$ and $250^{\circ} \mathrm{C}$ were selected for this study. Any higher inter-pass temperature would not have a practical benefit (especially for longer weld sections) as the weld initially cools very rapidly and only during the later stages the cooling rate is significantly reduced.

After completion of welding samples were prepared according to standard procedures for metallographic investigation and Vickers hardness testing

\subsection{Weld thermal history}

Resultant microstructure and hence mechanical properties of the HAZ are function of chemical composition of the steel, peak temperature and cooling cycle experienced during welding. Coarse-grain (CG) HAZ is the most susceptible to HACC out of all HAZ subzones. To demonstrate the effect of various levels of preheat on CGHAZ microstructure thermal profiles were acquired using technique of embedding thermocouples.

Weld thermal history of multi-pass joints was acquired to provide information about effects of various inter-pass temperatures on cooling rate and cooling times of the over-tempered region of the welded joint. For this purpose the thermocouples were spotwelded $15 \mathrm{~mm}$ from the edge of the plate.

\section{Results}

To confirm safety of the proposed welding procedures with reduced (ideally removed) preheat and increased inter-pass temperatures the information about the effect of various levels of these two temperatures on the HAZ microstructure and hardness is essential.

\subsection{Optimisation of preheat temperature}

\section{Weld thermal history}

From HACC view point the most important part of the thermal history is the cooling leg that will influence resultant microstructure, diffusible hydrogen level and also the residual stresses formed as a consequence of welding process. As mentioned previously CGHAZ is the most susceptible subzone thus the aim was to acquire thermal profile of this area. Measured peak temperature listed in Table 2 was in the range of $1349^{\circ} \mathrm{C}$ to $1411^{\circ} \mathrm{C}$ confirming that acquired thermal history was the measured in the CGHAZ.

Cooling time from $800^{\circ} \mathrm{C}$ to $500^{\circ} \mathrm{C}(\mathrm{t} 8 / 5)$ is usually selected to define the cooling cycle of a weldment. The susceptibility to HACC for various heat inputs and preheat conditions can be directly assessed based on this parameter. However the continuous cooling transformation investigation of the high strength steel used in this investigation revealed that transformation of HHA steel occurs in the temperature interval of $600^{\circ} \mathrm{C}$ to $200^{\circ} \mathrm{C}$ [3]. Therefore cooling time $\mathrm{t} 6 / 2$ more accurately represents cooling conditions crucial for evolution of microstructure. The hydrogen diffusion is the most active at high temperatures but continues to take place at lower temperatures at slower rate. The HACC typically occurs when temperature of the weldment drops below $200^{\circ} \mathrm{C}$; therefore overall cooling time from the peak temperature to $100^{\circ} \mathrm{C}(\mathrm{tp} / 1)$ most precisely describes the conditions for hydrogen diffusion.

Table 2 Cooling cycle characteristics (cooling time $\mathrm{t} 8 / 5$, t6/2 average cooling rate through $800^{\circ} \mathrm{C}-500^{\circ} \mathrm{C}$, and tp/1) measured for coarse-grain $\mathrm{HAZ}$ of single pass filet weldments preheated to $5^{\circ} \mathrm{C}, 20^{\circ} \mathrm{C}$ and $80^{\circ} \mathrm{C}$.

\begin{tabular}{|c|c|c|c|c|}
\hline Preheat temperature $\left({ }^{\circ} \mathbf{C}\right)$ & $\mathrm{Tp}\left({ }^{\circ} \mathrm{C}\right)$ & $\mathrm{t} 8 / 5(\mathrm{~s})$ & $\mathrm{t} 6 \times 2(\mathrm{~s})$ & $\mathrm{tp} / 1(\mathrm{~s})$ \\
\hline $\mathbf{5}$ & 1348 & 9.3 & 81 & 353 \\
\hline $\mathbf{2 0}$ & 1411 & 9,7 & 97 & 410 \\
\hline $\mathbf{8 0}$ & 1374 & 12,6 & 159 & 608 \\
\hline
\end{tabular}


From data presented in Table 2 it is obvious that increasing the preheat temperature resulted in longer cooling times and slower cooling rates through the whole course of cooling. The value of conventional parameter describing the cooling conditions t $8 / 5$ increased from $9.3 \mathrm{~s}$ to $12.6 \mathrm{~s}$ with increasing the preheat temperature from $5^{\circ} \mathrm{C}$ to $80^{\circ} \mathrm{C}$. The cooling time through the transformation region $\mathrm{t} 6 / 2$ doubled with increasing the level of preheat from $5^{\circ} \mathrm{C}$ to $80^{\circ} \mathrm{C}$. The overall cooling time from peak temperature to $100{ }^{\circ} \mathrm{C}$ tp $/ 1$ increased by $72 \%$ with increasing the level of preheat from $5^{\circ} \mathrm{C}$ to $80^{\circ} \mathrm{C}$.

\section{Weld hardness profiles}

Fundamental trend in hardness was gradual increase in across the entire weldment, with respect to decreasing the preheat temperature. This is due to the formation of harder microstructures as a result of increased cooling rate. From the graph presented in Figure 3 it can be observed that CGHAZ hardness increased by approximately $50 \mathrm{HV}$ with decreasing preheat temperature from $80^{\circ} \mathrm{C}$ to $5^{\circ} \mathrm{C}$. The hardness of over-tempered (OT) region gradually increased by $30 \mathrm{HV}$ and the width decreased by $3 \mathrm{~mm}$ with decreasing preheat from $80^{\circ} \mathrm{C}$ to $5^{\circ} \mathrm{C}$.

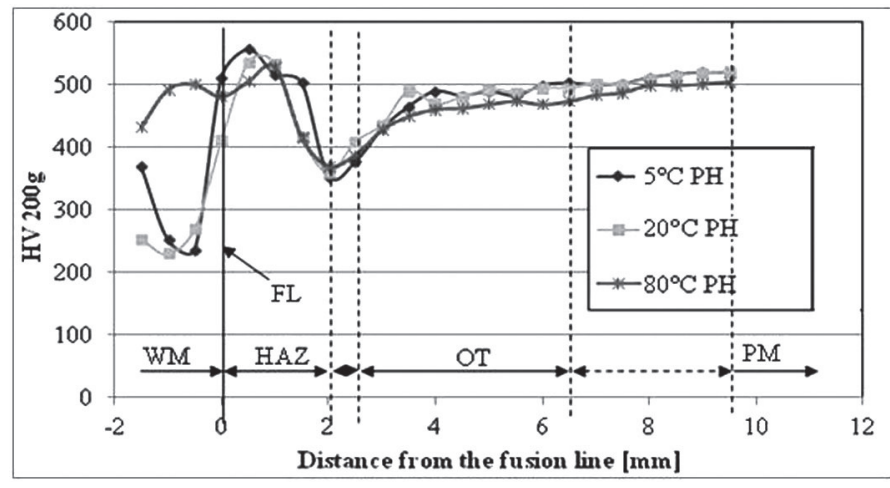

Figure 3 Weld hardness profiles of the 1 pass filet joints welded employing preheat temperatures of $5^{\circ} \mathrm{C}, 20^{\circ} \mathrm{C}$, and $80^{\circ} \mathrm{C}$.

\section{CGHAZ microstructure}

The microstructure of the CGHAZ of the 1 pass fillet weld is presented in Figure 4. Samples preheated to $80^{\circ} \mathrm{C}$ consisted of mixture of upper and lower bainite and lath martensite. Ferrite was also present in the form of very fine ferritic laths of
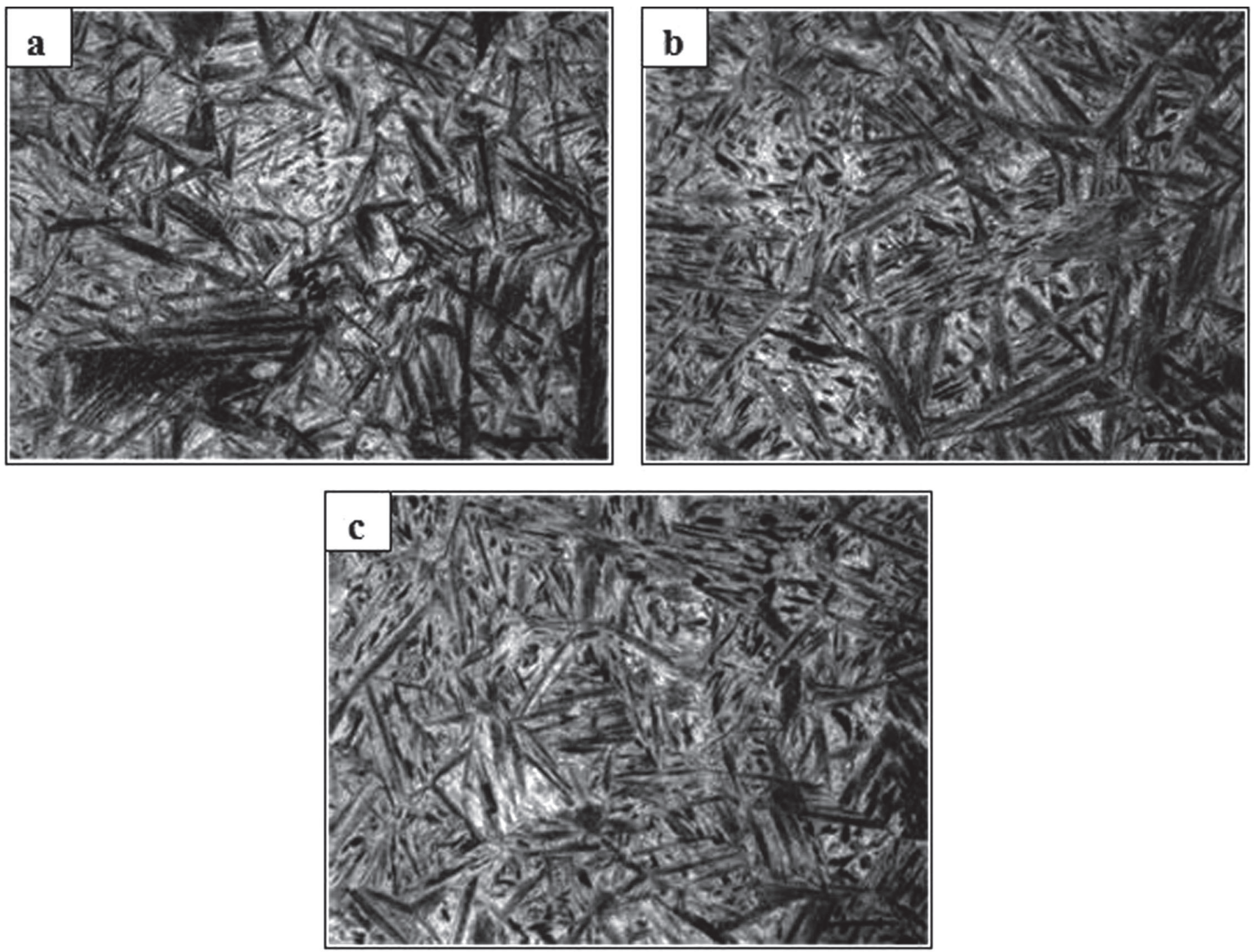

Figure 4 Microstructure of the coarse-grained HAZ subzone of the 1 pass fillet welds deposited using various levels of preheat: a $80^{\circ} \mathrm{C}, \mathrm{b}-20^{\circ} \mathrm{C}, \mathrm{c}-5^{\circ} \mathrm{C}$. Note: micron bar represents 20 micrometers. 
upper bainite. When $20^{\circ} \mathrm{C}$ preheat temperature was employed ferritic laths were no longer present in the structure of coarsegrained region. Lowering the preheat temperature favoured the formation of higher volume fraction of harder phases and the microstructural features became finer. The amount of martensite increased at the expense of bainite with lowering the preheat temperature.

\subsection{Optimisation of inter-pass temperature}

The cooling time data presented Table 3 show that increasing inter-pass temperature from $120^{\circ} \mathrm{C}$ to $250^{\circ} \mathrm{C}$ reduced the welding time (from the peak temperature of the first cap pass [tp(1st pass)] until the peak temperature of the final pass was reached [tp(final pass)]) from $923 \mathrm{~s}$ to 203s. These data are particularly significant to industry and are a useful tool to gauge productivity gains during fabrication. Increasing the inter-pass temperature to $200^{\circ}$ and $250^{\circ} \mathrm{C}$ resulted in reduction in cooling time of approximately 10 minutes (66\%) and 12 minutes (78\%). Overall cooling time (from the peak temperature of the first cap pass $[\operatorname{tp}(1 \mathrm{st}$ pass $)]$ until $100^{\circ} \mathrm{C}$ was reached after completion of welding $\left[\mathrm{t} 100^{\circ} \mathrm{C}\right.$ (final pass) $]$ ) was gradually reduced from $1904 \mathrm{~s}$ to $1400 \mathrm{~s}$ with the increase of inter-pass temperature from $120^{\circ} \mathrm{C}$ to $250^{\circ} \mathrm{C}$. Overall cooling time data is important in assessing time taken for cooling with respect to diffusion of hydrogen out of the weldment during the welding process.

Table 3 Cooling times of the cap passes of the corner joint.

\begin{tabular}{|c|c|c|c|}
\hline Interpass temperature $\left({ }^{\circ} \mathrm{C}\right)$ & 120 & 200 & 250 \\
\hline $\begin{array}{l}\text { Cooling time }\left\{\mathrm{t}_{\mathrm{p}}\left(1^{\text {st }} \text { pass }\right)\right. \\
\left.\text { to } \mathrm{t}_{\mathrm{p}}\left(3^{\text {rd }} \text { pass }\right)\right\}[\mathrm{sec}]\end{array}$ & 923 & 315 & 203 \\
\hline $\begin{array}{l}\text { Cooling time }\left\{\mathrm{t}_{\mathrm{p}}\left(1^{\text {st }} \text { pass }\right)\right. \\
\left.\text { to } \mathrm{t}_{10^{\circ} \mathrm{c}}\left(3^{\text {rd }} \text { pass }\right)\right\}[\mathrm{sec}]\end{array}$ & 1904 & 1486 & 1400 \\
\hline
\end{tabular}

\section{Weld hardness profiles}

It was observed that with an increase in inter-pass temperature, a gradual decrease in HAZ hardness was found to occur, as a result of slower cooling rates in transformation region promoting formation of softer microstructures. The maximum difference between $\mathrm{HAZ}$ hardness at $120^{\circ} \mathrm{C}$ and $250^{\circ} \mathrm{C}$ was approximately $150 \mathrm{HV}$. In addition, the $\mathrm{HAZ}$ widths for all interpass temperatures were very similar, with only slight increases of maximum $0.5 \mathrm{~mm}$. Hardness profiles measured in the OT region were found to be almost identical with only very slight decrease in hardness with increasing the inter-pass temperature to $200^{\circ} \mathrm{C}$. Further increase to $250^{\circ} \mathrm{C}$ resulted in somewhat higher degree of softening of maximum $50 \mathrm{HV}$. The width of the OT increased with increasing cooling rate from $120^{\circ} \mathrm{C}$ to $250^{\circ} \mathrm{C}$ by $3.5 \mathrm{~mm}$

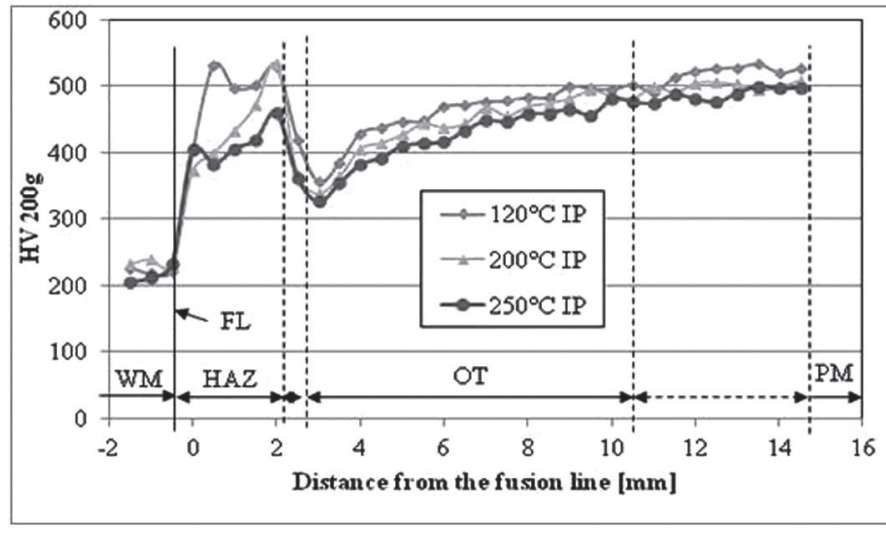

Figure 5 Weld hardness profiles measured in B orientation of the multi pass corner joints welded with interpass temperatures of $120^{\circ} \mathrm{C}, 200^{\circ} \mathrm{C}$ and $250^{\circ} \mathrm{C}$.

\section{Microstructure of OT region}

When welding high strength steel in Q\&T condition the deposition of multiple passes can result in formation of extensively wide softened regions especially when high interpass temperatures or high heat inputs are employed. Therefore the microstructure of OT region was subjected to close examination and micrographs are presented in Figure 7.

The microstructure of all investigated weldments consisted predominantly of tempered martensite. Increasing interpass temperature for $120^{\circ} \mathrm{C}$ to $250^{\circ} \mathrm{C}$ appears to have little to no effect on the microstructure of OT region. This observation is consistent with hardness data presented in previous section.

\section{Discussion}

\subsection{Optimisation of preheat}

To be able to confirm the safety of proposed lower preheat temperature is necessary to assess the influence preheat reduction on all three factors contributing to HACC (microstructure, diffusible hydrogen and weld residual stresses).

\section{Microstructure and hardness}

From microstructural view point decreasing the preheat temperature from $80^{\circ} \mathrm{C}$ to $5^{\circ} \mathrm{C}$ produces slightly harder structures. However GGHAZ of the weldments produced employing both levels of preheat comprises of hard and brittle bainitic and martensitic constituents. The difference between the two levels of preheat is that joint simulating preheat temperature of $5^{\circ} \mathrm{C}$ contains higher martensite to bainite ratio compared to the one welded utilising $80^{\circ} \mathrm{C}$ preheat. Also HAZ hardness of the joints welded employing both preheats is very high, well about the level considered to be safe from HACC view point. The AS/NZS 1554.4 standard [4] states that even when welding Q\&T steels employing low hydrogen consumable, maximum allowable HAZ hardness ensuring freedom from HACC is 450 $\mathrm{HV}$. This critical hardness value is considered when welding 

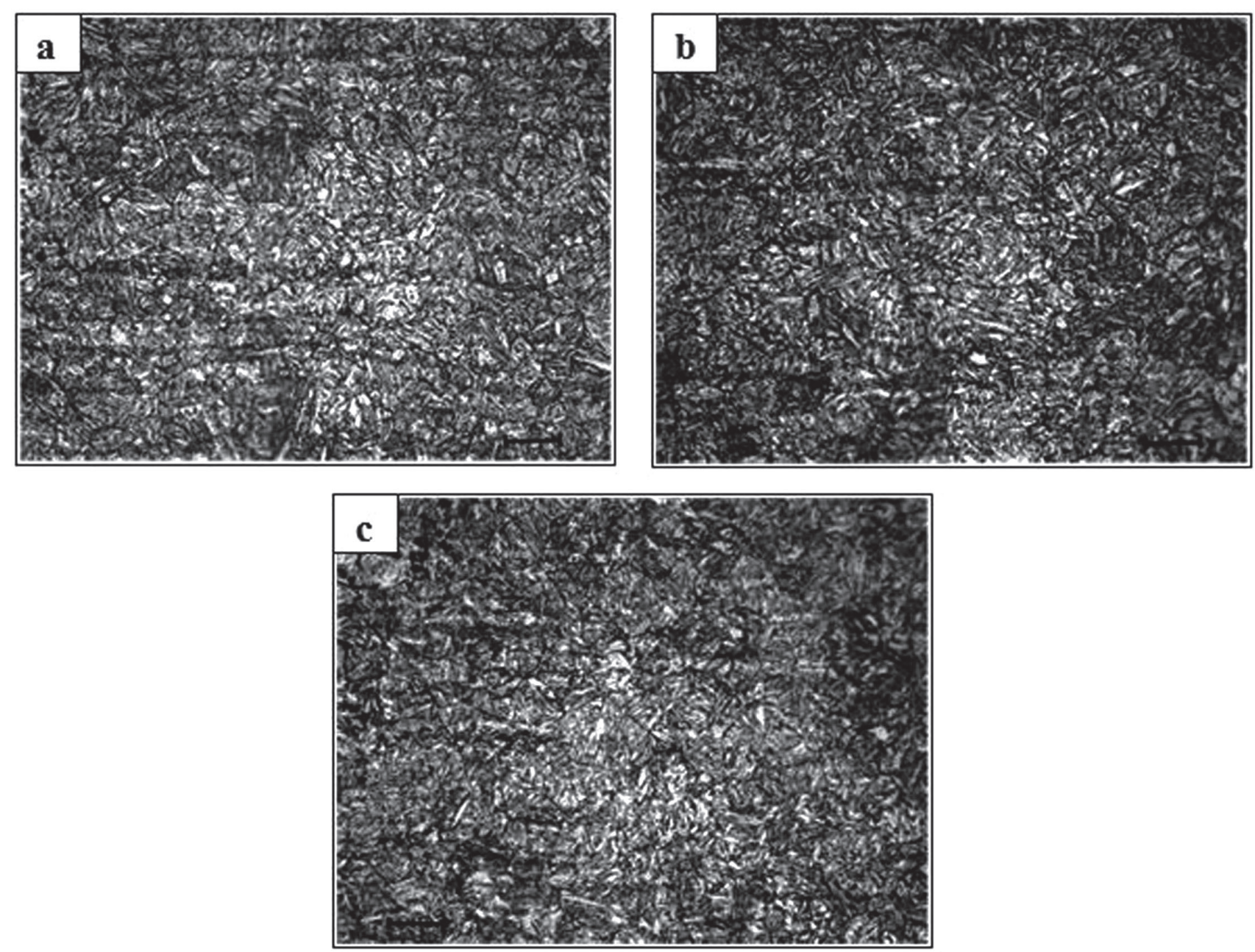

Figure 6 Microstructure of the over-tempered HAZ region of the multi-pass corner welds deposited employing interpass temperatures of: a $-120^{\circ} \mathrm{C}, \mathrm{b}-200^{\circ} \mathrm{C}$, and c $-250^{\circ} \mathrm{C}$. Note: micron bar represents 20 micrometers.

utilising ferritic consumable. However, the industry procedures previously used for welding this high strength Q\&T steel employed ferritic consumable in combination with $80^{\circ} \mathrm{C}$ that resulted in HAZ hardness levels above $500 \mathrm{HV}$. Slightly higher hardness obtained in the HAZ as a result of elimination of preheat is expected to be compensated by the ability of austenitic stainless steel weld metal to accommodate higher hydrogen and stress levels.

\section{Diffusible hydrogen level}

Results of previous work [5] revealed that weldments produced employing identical metal-cored austenitic stainless steel consumable as used in present study resulted in very low levels of diffusible hydrogen of $0.5 \mathrm{ml}$ of hydrogen per $100 \mathrm{~g}$ of weld metal. In fact previously used flux-cored ferritic consumable introduced 18 times more diffusible hydrogen into the weld pool compared to austenitic stainless steel filler. The study further revealed that preheat level in range of $5^{\circ} \mathrm{C}$ to $80^{\circ} \mathrm{C}$ had only minor effect on the value of the measured diffusible hydrogen measured for welds produced utilising ASS consumable.

\section{Weld residual stresses}

Austenite has considerably higher coefficient of thermal contraction than ferrite (typically 18 and $14 \times 10^{-6} /{ }^{\circ} \mathrm{C}$ in the range of $1{ }^{\circ} \mathrm{C}-100^{\circ} \mathrm{C}$ for austenitic and ferritic steel respectively) thus the overall contraction is higher than that of ferritic weld metal. However ASS weld metal possesses increased ability to yield and hence compensate thermal contraction resulting in limited evolution of residual stresses compared to ferritic weld metal [6]. Due to these phenomena residual stresses in joints welded with ASS consumable are likely to be lower compared to ferritic consumables, even though the lower preheat temperature is employed. In addition, on cooling HAZ of the parent material undergoes martensitic transformation that is accompanied by volume expansion which to certain extent compensates the thermal shrinkage.

\subsection{Optimisation of inter-pass temperature}

\section{Microstructure and hardness}

Increasing inter-pass temperature to $250^{\circ} \mathrm{C}$ had a beneficial 
influence on HAZ through slightly reducing the hardness levels. Formation of softer microstructures especially in coarse-grained region could have beneficial effects with respect to reducing the potential risk of HACC._Hardness of OT region exhibited only minor degree of softening with increasing inter-pass temperature from $120^{\circ} \mathrm{C}$ to $200^{\circ} \mathrm{C}$. Slightly higher softening was observed with further increase of inter-pass temperature to $250^{\circ} \mathrm{C}$. However this temperature was investigated as the worst case scenario to expand the temperature window when depositing short welds.

The main concern when employing higher inter-pass temperatures for welding high strength Q\&T steel is formation of wide extensively softened areas in the over-tempered region that could compromise the mechanical properties of the welded structure. On the other hand resulting prolonged cooling times after deposition of final pass favour the diffusion of the hydrogen and also temper rehardened HAZ areas thus reducing the risk of HACC. These effects are likely to compensate implication resulting from employing proposed lower level of preheat for multi-pass joints.

\section{Conclusions}

Results of this and previous work suggest that for welding high strength Q\&T steel with ASS consumable decreasing preheat temperature from $80^{\circ} \mathrm{C}$ to $5^{\circ} \mathrm{C}$ is safe in terms of HACC. Further in case of multi-pass welding the implications of increased cooling rate resulting from preheat reduction are likely to be compensated by employing proposed higher interpass temperature. The nature of an austenitic stainless steel filler has the potential to remove the preheat requirement, what would allow great benefits during welding fabrication in terms of time and costs for industry as the whole technological step of preheating could be avoided.

Findings of this investigation also revealed that increasing inter-pass temperature up to $250^{\circ} \mathrm{C}$ does not lead to formation of wide extensively softened areas when compare to weldments produced employing inter-pass temperature of $120^{\circ} \mathrm{C}$. Employing higher inter-pass temperature would also have a great positive impact on productivity.

\section{References}

[1] WTIA, WTIA Technical Note No. 15 - Welding \& fabrication of quenched and tempered steel 1996, WTIA.

[2] ISO/TR 17844: Welding - Comparison of standardised methods for the avoidance of cold cracks. 2004, International Organization for Standardization: Geneva.

[3] Kuzmikova, L., et al., A Study of the Continuous Cooling Behaviour of High Strength Quenched and Tempered Steel in 63rd Annual Assembly \& International Conference of the International Institute of Welding. 2010: Istanbul, Turkey.

[4] AS/NZS 1554.4:2010: Structural steel welding - Welding of high strength quenched and tempered steels 2010, Standards Australia.

[5] Kuzmikova, L., et al., Research to establish a systematic approach to safe welding procedure development using austenitic filler material for fabrication of high strength steel, in 16th International Conference on the Joining of Materials. 2011: Helsinki, Denmark.

[6] Bhadeshia, H.K.D.H., Developments in martensitic and bainitic steels: Role of the shape deformation. Materials Science and Engineering A, 2004. 378(1-2 SPEC. ISS.): p. 34-39. 